\title{
Influence of transit water flow rate on its dispensation and on inflow through nozzles in pressure pipeline under action of external pressure
}

\author{
V.V. Cherniuk ${ }^{1,2}$, O.A. Riabenko3 ${ }^{3}$, V.V. Ivaniv ${ }^{1}$ \\ ${ }^{1}$ Lviv Polytechnic National University, UKRAINE, 79013, Lviv, S. Bendery Street 12 \\ ${ }^{2}$ Catholics University of Lublin named after John Paul II, Republic of Poland \\ ${ }^{3}$ National University of Water Management and Nature Resources Use, UKRAINE, 33028, Rivne, Soborna Street 11
}

\begin{abstract}
The influence of transit flow rate of water upon operative of the equipped with nozzles pressure pipeline is experimentally investigated. External pressure, which varies in the range of $1465-2295 \mathrm{~mm}$, acted upon the pipeline. The angle $\beta$ between vectors of velocities of the stream in the pipeline and jets which branch off through nozzles were given the value: $0^{o} ; 45^{o} ; 90^{\circ} ; 135^{\circ} ; 180^{o}$. The diameter of the pipeline was of $\mathrm{D}=20.18 \mathrm{~mm}$, the diameter of nozzles $\mathrm{d}=6.01 \mathrm{~mm}$. The distances between the nozzles were $180 \mathrm{~mm}$, and the number of them 11. The value of the transit flow rate at input into the pipeline varied from 4.05 to $130.20 \mathrm{~cm}^{3} / \mathrm{s}$. The increase in flow rate of the transit flux $Q_{t r}$ caused increase in non-uniformity of distribution of operating heads and increase in flow rate of water along the pipeline over the segment of its dispensation. On the segment of collecting of water, inverse tendency was observed. The number of nozzles through which water became to be dispensed increased with the increase in $Q_{t r}$.
\end{abstract}

Key words: dispensation pipeline, pipeline-collector, variable mass fluid flow

\section{Introduction}

Pressure pipeline with variable flow rate of fluid along the path are widely used in many industrial processes - pipeline-collector (PC) and distribution pipeline (DP). PCs are widespread in water-supply (water-intake structures with tubular heads), in amelioration (drainage systems), depreciation, ventilation (exhaust systems) [1, c. 312-317, 2], ets. DPs are used in irrigation (drip irrigation), water supply in fire-fighting systems, drainage systems (dispersed release of wastewaters) [1, c. 252-272]) and others. In overwhelming majority, manufacturing processes call for ensuring of uniform operation of PC and DP. In the known works [3-5], operation of pipelines only with orthogonal inflow or outflow jets and under the absence of transite fluid flow is investigated.

Aim of the work: to investigate the influence of transit flow rate of water on non-uniformity in operation of the pressure pipeline with nozzles, which depends on the values of the angles 
between directions on the flow of the main stream in the pipeline and the direction of the transit jets which inflow or outflow.

\section{Experimental Set-up}

The schematic diagram of operation of the experimental set-up and detailed description of it are presented in [6]. The experimental pipeline, which is made of brass, whose inner diameters is of $\mathrm{D}=20.18 \mathrm{~mm}$ and whose length is of $\mathrm{L}=2494 \mathrm{~mm}$ is installed in watertight case 4 (Fig. 1). In the wall of experimental pipeline, eleven nozzles (Fig. 2) are fixed with the possibility to rotate them about their longitude axes. By means of rotation of the nozzles, the angles $\beta$ between the vectors of velocities of the main srteam in the pipeline and the inflowing an outflowing jets was adjusted (Fig. 3). The inner diameters of the nozzles were of $\mathrm{d}=6.01 \mathrm{~mm}$. The distances between them are egual to $180 \mathrm{~mm}$. The angle $\beta$ was assigned the values: $0^{\circ} ; 45^{\circ} ; 90^{\circ} ; 135^{\circ} ; 180^{\circ}$. The values of transite flow rate $Q_{t r}$ of water varied from 4.05 to $130.20 \mathrm{~cm}^{3} / \mathrm{s}$, and the water head $H$ outside the pipeline (in the watertight case) from 1465 to $2295 \mathrm{~mm}$. The Reynolds criterion $R e_{D}$ varied within 11925...18890. The temperature of water was of $T=18.0-24.0^{\circ} \mathrm{C}$. The schematic diagram of water heads, which act upon the water stream in the experimental pipeline, is presented in Fig.1.

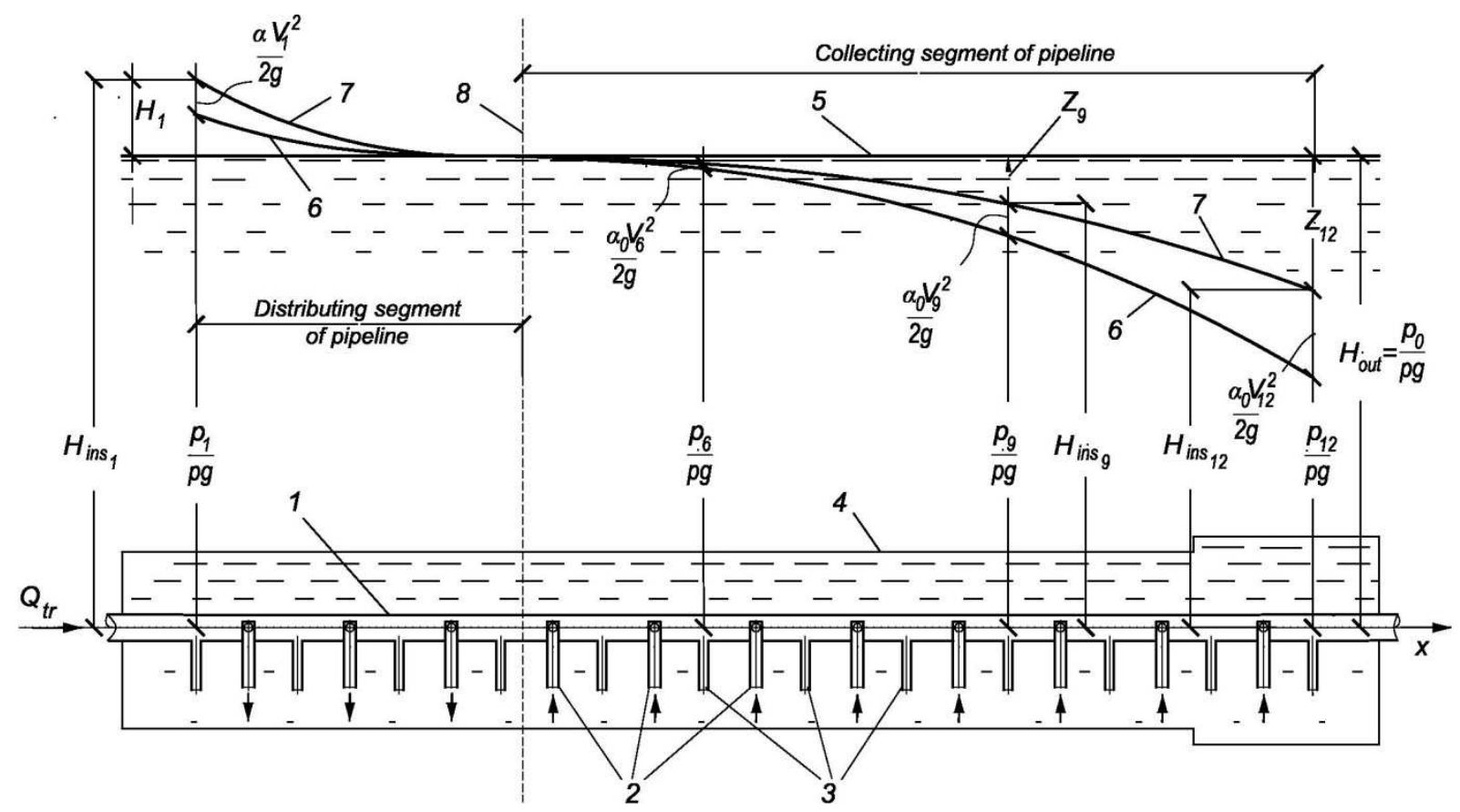

Figure 1: Schematic diagram of heads which act upon streams in experimental pipeline with nozzles: 1 -experimental pipeline; 2 -nozzles; 3 - unions for connection of pulse lines from piezometers; 4 -watertight case; 5 -water level which corresponds to the head in watertight case; 6 - piezometric line for water stream inside pipeline; 7 -ditto for complete working head; 8 - boundary between DP and PC; $\mathrm{x}$ - axis of pipeline 


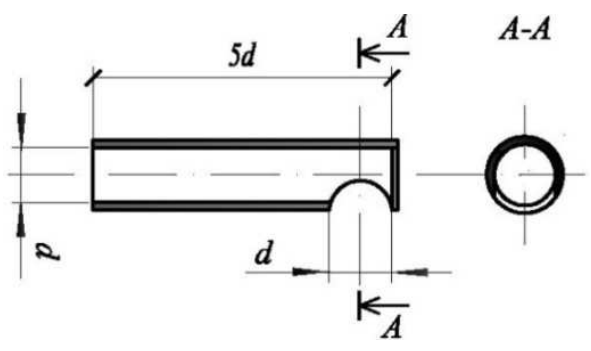

a)

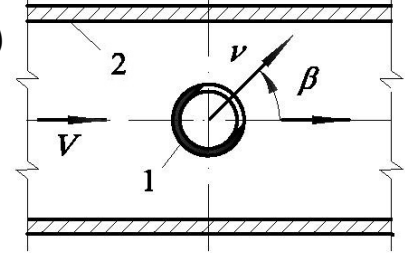

b)

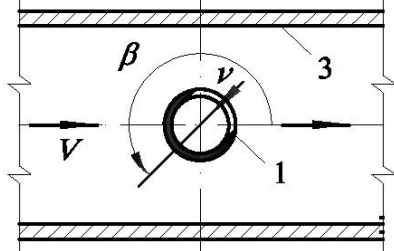

Figure 2: Cylindrical nozzles with orthogonal lateral inlet in the case of PC or orthogonal lateral outlet in the case of DC

Figure 3: Schematic diagram of reference of angle $\beta$ : (a) - for PC; (b) - for DP. 1 - cylindrical nozzle (crosssection, $\beta=45^{\circ}$ for $\mathrm{PC}$ or $\beta=225^{\circ}$ for DP); 2 - wall of PC; 3 - wall of DP; V - mean speed of main stream in pipeline; $\mathrm{v}-$ ditto for jet

\section{Mathematical processing of experimental data}

The working head $H_{i}$ at the $\mathrm{i}^{\text {th }}$ from the beginning of the experimental pipeline outlet nozzle and, correspondingly, the working head $Z_{i}$ at the inlet nozzle are the following:

$$
H_{i}=H_{\text {out }}-\frac{p_{i}}{\rho g}-\frac{\alpha_{0} V_{i}^{2}}{2 g}, \quad(1, a) \quad Z_{i}=H_{\text {out }}-\frac{p_{i}}{\rho g}-\frac{\alpha_{0} V_{i}^{2}}{2 g},
$$

where, $H_{\text {out }}$ is the actual head outside the pipeline; $p_{i} / \rho g$ is the piezometric head at the $\mathrm{i}^{\text {th }}$ nozzle; $\quad \alpha_{0} V_{i}^{2} / 2 g$ is the kinetic-energy head of the stream inside the pipeline in front of the location of the $\mathrm{i}^{\mathrm{th}}$ nozzle. The value of $H_{i}$ in the segment of water dispensation was written with minus sign because the full complete head $H_{\text {ins }}$ of the stream in the DP was greater than the head $H_{\text {out }}$ outside it (Fig. 1).

The dispensation of water out of the pipeline into the watertight case or its inflow into the pipeline through the $i^{\text {th }}$ nozzle was calculated theoretically in the following way:

$$
q_{\text {i.нас.PT }}=\mu_{i} \omega \sqrt{2 g H_{i}}, \quad \quad(2, a) \quad q_{\text {i.нас. } 3}=\mu_{i} \omega \sqrt{2 g Z_{i}},
$$

where, $\mu_{i}$ is the coefficient of flow rate of the $\mathrm{i}^{\text {th }}$ inlet nozzle, its value $\mu=f\left(R e_{d}\right)$ is determined in experimental way [7]; $\omega$ is the cross-section area of the nozzle; $g$ is the gravity acceleration; $H_{i}$ is the working head at the outlet nozzle; $Z_{i}$ is ditto at the inlet nozzle (1). 
The flow rate of water in the experimental pipeline at the location of the $\mathrm{k}^{\text {th }}$ nozzle was calculation with taken into account the expressions (1) and (2) according to the formula:

$$
q_{k}=\sum_{i=1}^{k} q_{i}+\mu_{k} \omega \cdot \sqrt{\left[2 g H_{\text {out }}-\frac{2 p_{k}}{\rho}-\alpha_{0}\left(\sum_{i=1}^{k-1} \frac{q_{i}}{\Omega}\right)^{2}\right]}
$$

where, $\sum_{i=1}^{k} q_{i}$ is the water flow rate in the location of the pipeline in front of the $\mathrm{k}^{\text {th }}$ nozzle; $\mu$ is the coefficient of flow rate of the nozzle number $k ; \Omega, \omega$ are the cross-section areas of the pipeline and the nozzle, respectively; $H_{\text {out }}$ is the actual head outside the pipeline; $p_{k} / \rho g$ is the piezometric head at the $\mathrm{k}^{\mathrm{th}}$ nozzle;; $a_{0}$ is the Coriolis coefficient, $a_{0}=1.05$.

The non-uniformity of the dispensation of working head out of the DP $(3, a)$ and that inside the PC $(3, b)$ are determined in the following way [8]:

$$
\eta_{H}^{P T}=H_{\text {beg }} / H_{i} \quad(3, a) \quad \eta_{Z}^{T 3}=Z_{i} / Z_{\text {end }}
$$

where, $H_{b e g}$ and $H_{i}$ are heads at the first and at the $\mathrm{i}^{\text {th }}$ outlet nozzles, respectively, of the segment of the DP; $Z_{i}$ and $Z_{\text {end }}$ are the heads at the $i^{\text {th }}$ and at the last inlet nozzles, respectively.

The non-uniformity of the dispensation of water out of the DP $(4, a)$ and that inside the PC $(4, b)$ are determined in the following way [8]:

$$
\eta_{Q}^{P T}=Q_{\text {beg }} / Q_{i} \quad(4, a) \quad \eta_{Q}^{T 3}=Q_{i} / Q_{\text {end }}
$$

where, $Q_{b e g}, Q_{i}$ are the water flow rates behind the firs nozzle and in the $\mathrm{i}^{\mathrm{th}}$ cross-section of the DP, respectively; $Q_{i}, Q_{\text {end }}$ are the water flow rates in the $i^{\text {th }}$ cross-section and behind the last nozzle, respectively; of the inlet segment of the PC.

\section{Results of experimental investigation}

The distribution of working heads $H$ in the segment of DP and that of the PC $Z$ as well as distribution of water flow rates $Q$ in the experimental pipeline are presented in relative coordinates (Fig. 4-Fig.8). In each experiment, all the nozzles are installed with equal value of the angle $\beta$. Since the direction of water flow in the inlet nozzles changes to the opposite one, the angle of inflow jets was by $180^{\circ}$ less as compared to the outlet nozzles [9].

From the results of the investigations, it can be seen that for the greater value of flow rate of the transit flow there corresponds the greater number of nozzles through which the water becomes to be dispensed. This can be accounted for by the following: the transit stream with greater water flow rate flows fasters, thus, it has greater kinetic energy; besides, the piezometric head $H_{l}$ in the segment of water dispensing is higher that the head $H_{\text {out }}$, which acts outside the pipeline. We consider for that shortening of distributing segment it is necessary to create such conditions under which the transit stream spends its energy completely. 

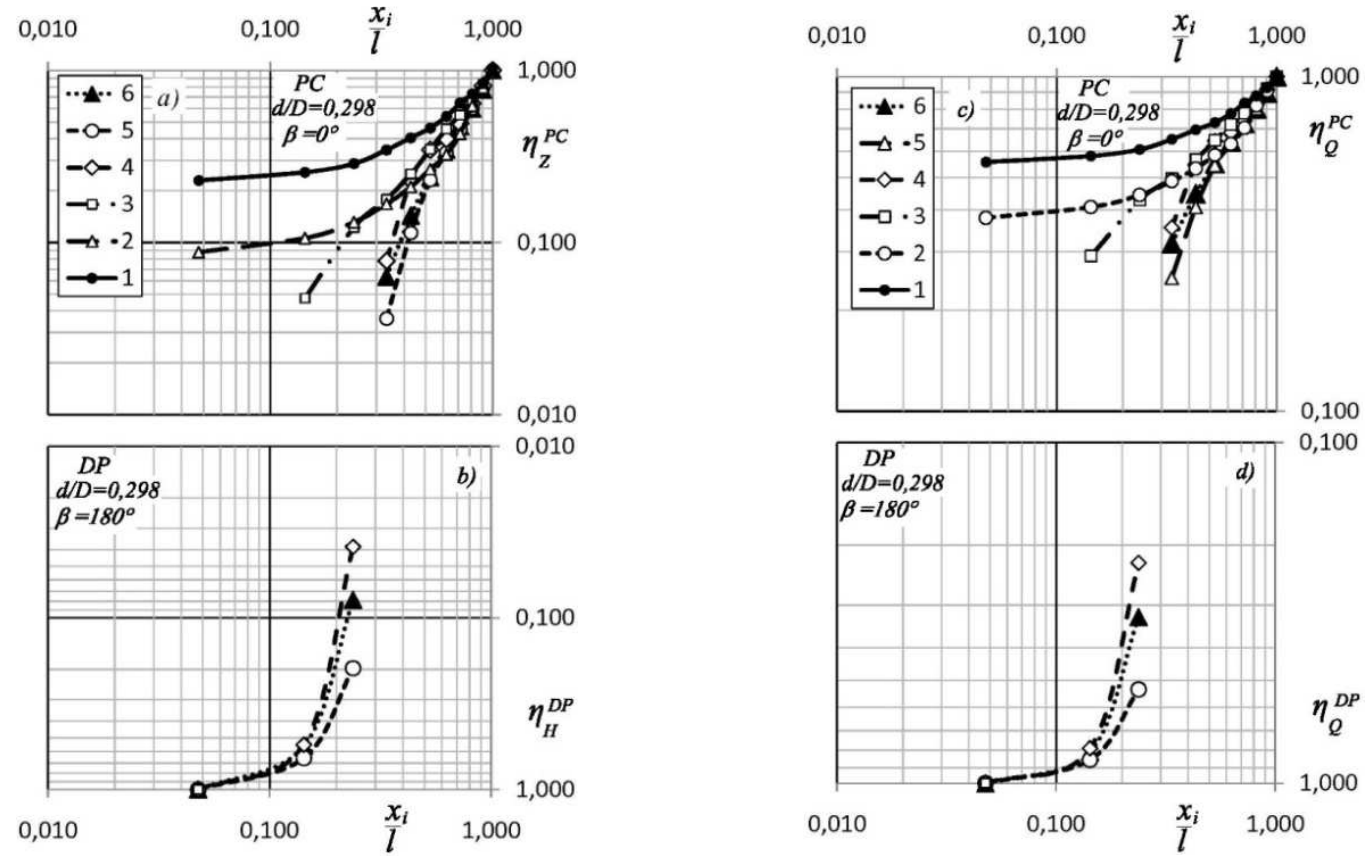

Figure 4: Distributions: (a) of working heads in PC and (b ) ditto for DP; (c) of water flow rate in PC and (d) ditto for DP. The distributions correspond to jet angles of inflow, $\beta=0^{\circ}$, and of outflow, $\beta=180^{\circ}$, for different values of $Q_{t r}$ in $\mathrm{cm}^{3} / \mathrm{s}: 0.00$ - (1); 21.37 - (2); 49.24 - (3); 81.38 - (4); 119.01 - (5); 130.17 - (6)
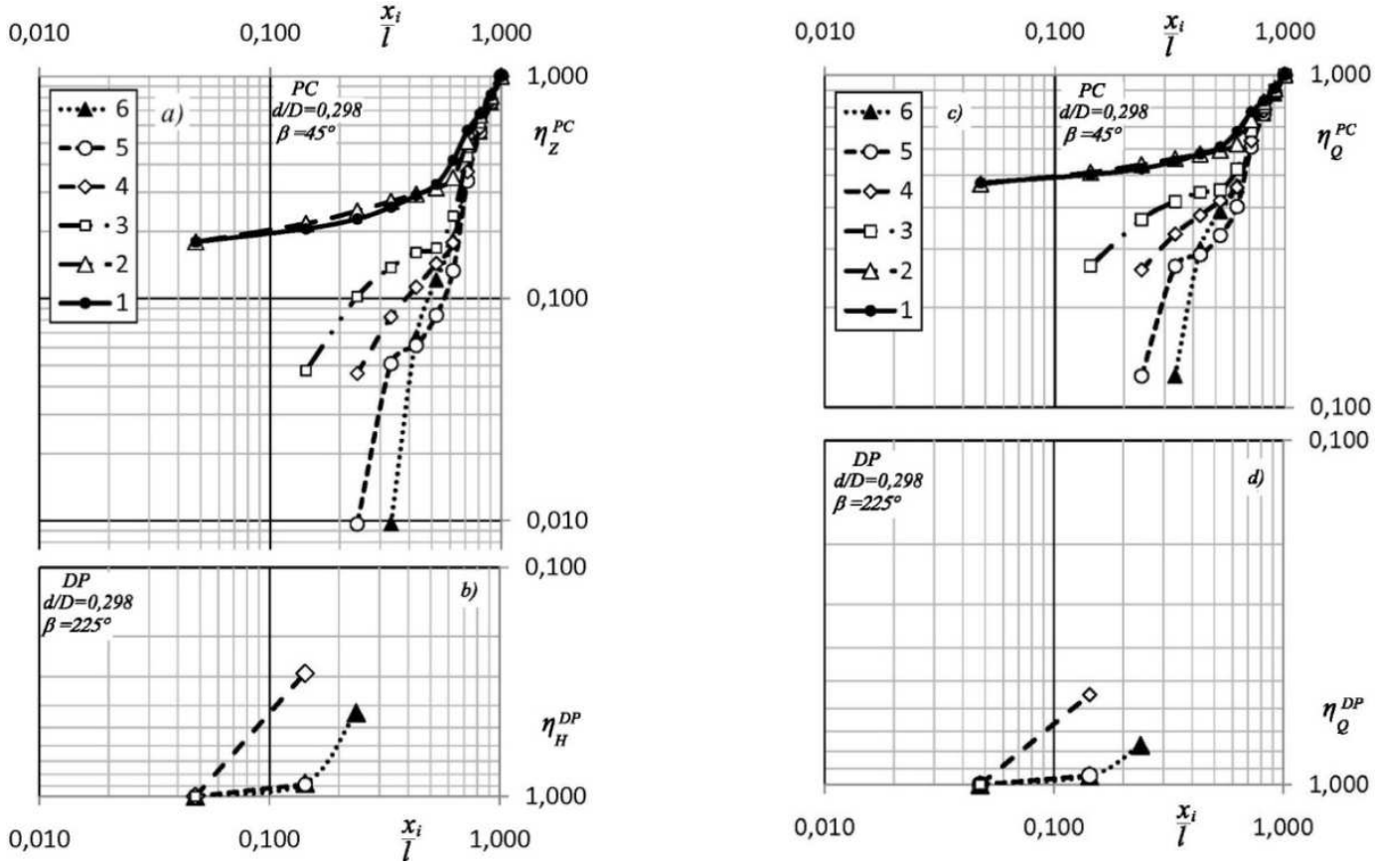

Figure 5: Distributions: (a) of working heads in PC and (b) ditto for DP; (c) of water flow rate in PC and (d) ditto for DP. The distributions correspond to jet angles of inflow, $\beta=45^{\circ}$, and of outflow, $\beta=225^{\circ}$, for different values of $Q_{t r}$ in $\mathrm{cm}^{3} / \mathrm{s}: 0.00-(1) ; 7.20-(2)$; 50.76 - (3); 85.37 - (4); 116.78 - (5); 128.37 - (6) 

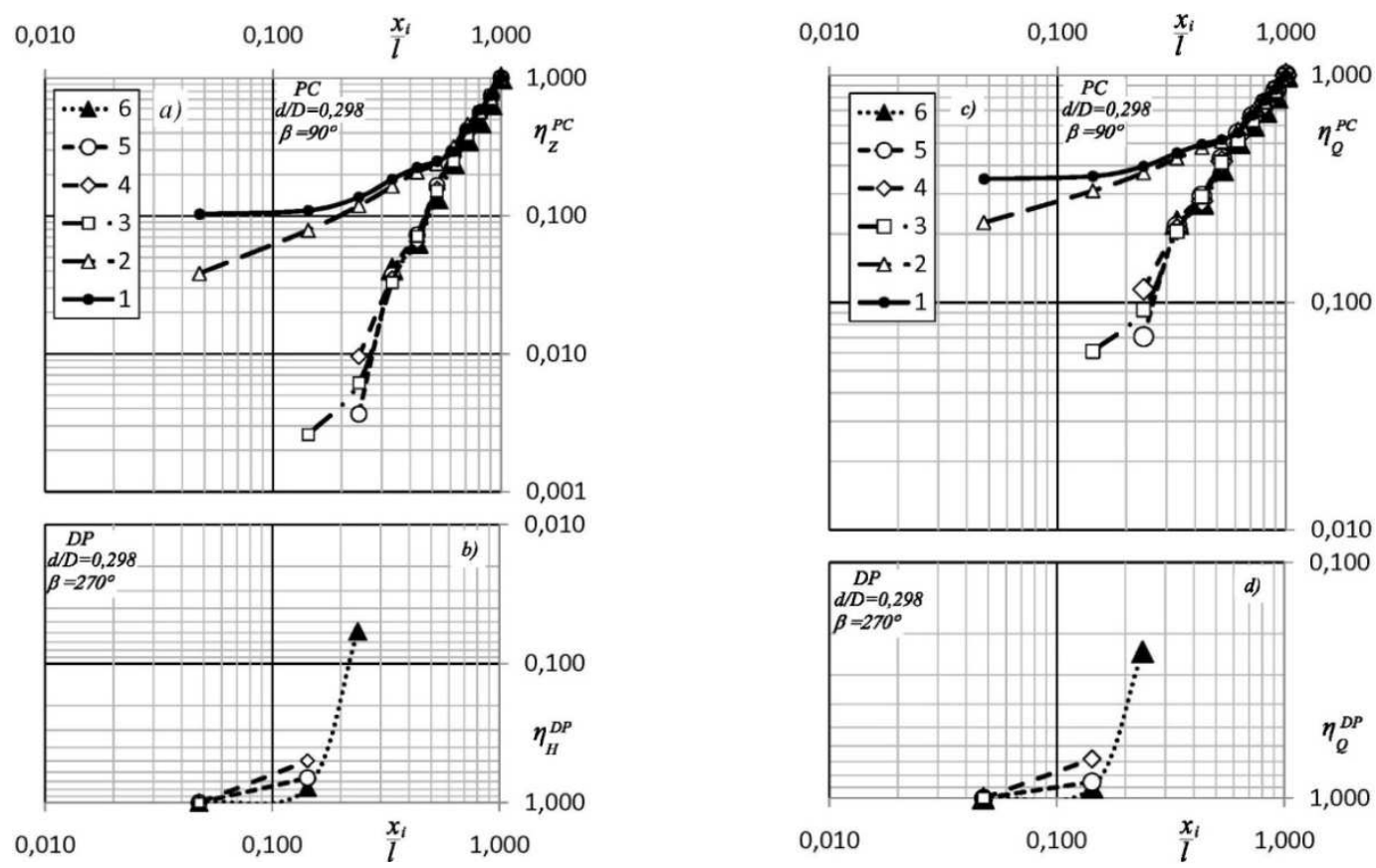

Figure 6: Distributions: (a) of working heads in PC and (b) ditto for DP; (c) of water flow rate in PC and (d) ditto for DP. The distributions correspond to jet angles of inflow, $\beta=90^{\circ}$, and of outflow, $\beta=270^{\circ}$, for different values of $Q_{t r}$ in $\mathrm{cm}^{3} / \mathrm{s}: 0.00$ - (1); 9.35 - (2); 77.52 - (3); 99.98 - (4); 115.97 - (5); 128.34 - (6)
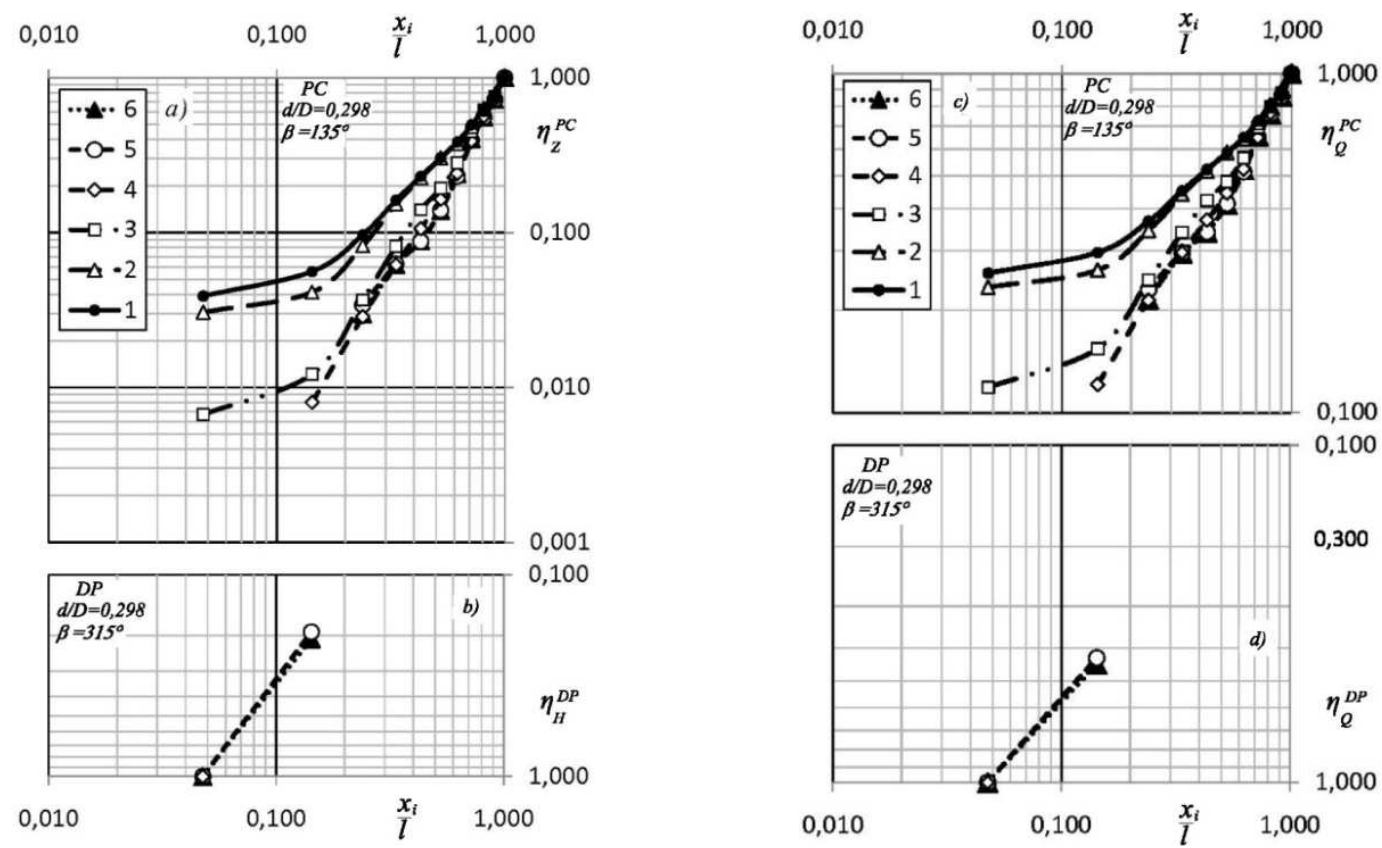

Figure 7: Distributions: (a) of working heads in PC and (b) ditto for DP; (c) of water flow rate in PC and (d) ditto for DP. The distributions correspond to jet angles of inflow, $\beta=135^{\circ}$, and of outflow, $\beta=315^{\circ}$, for different values of $Q_{t r}$ in $\mathrm{cm}^{3} / \mathrm{s}: 0.00$ - (1); 7,19 - (2); 52.65 - (3); 99.27 - (4); 116.56 - (5); 126.02 - (6) 

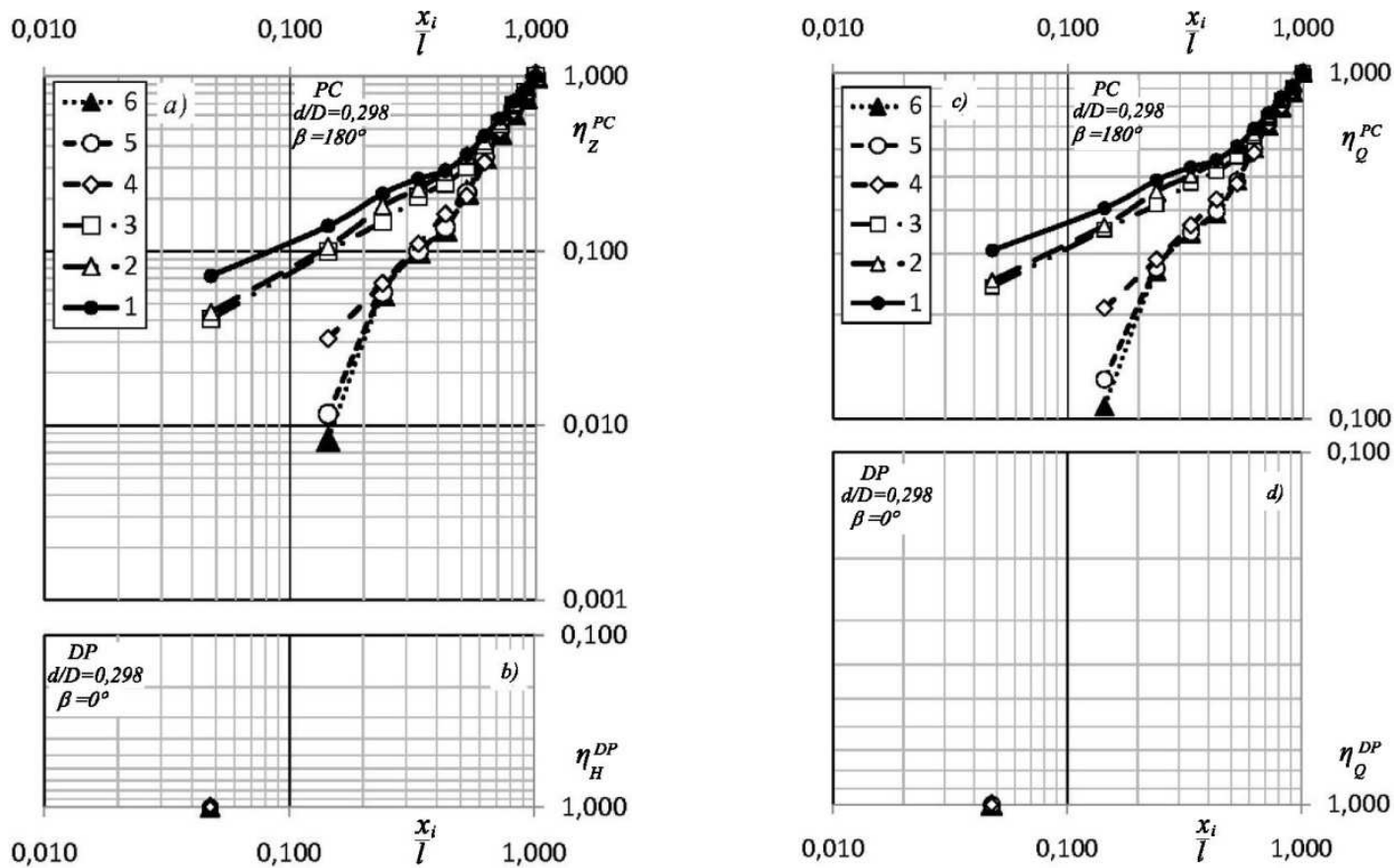

Figure 8: Distributions: (a) of working heads in PC and (b) ditto for DP; (c) of water flow rate in PC and (d) ditto for DP. The distributions correspond to jet angles of inflow, $\beta=180^{\circ}$,

and of outflow, $\beta=0^{O}$, for different values of $Q_{t r}$ in $\mathrm{cm}^{3} / \mathrm{s}: 0.00$ - (1); 4.06 - (2);

$$
25.55 \text { - (3); } 83.63 \text { - (4); } 104.34 \text { - (5); } 122.60 \text { - (6) }
$$

For example, this can be done by means of increasing the hydraulic resistance of initial segment of pipeline and decreasing the outlet holes of the dispensing nozzles.

The investigations have indicated that for the inflow jet angle of $\beta=180^{\circ}$ (Fig. 8,a,c), and correspoudingly, for the outflow jet angle of $\beta=0^{\circ}$ (Fig. 8,b,d), under variation of value of the transite flow rate $Q_{t r}$ from 83.66 to $122.60 \mathrm{~cm}^{3} / \mathrm{s}$, the water-dispensing segment includes only one nozzle. And for the inflow jet angle $\beta=0^{\circ}\left\{180^{\circ}\right.$ for outflow $\}$ with the variation of $Q_{t r}$ from 81.38 to $130.17 \mathrm{~cm}^{3} / \mathrm{s}$ the length of the dispensing segment of the pipeline includes three nozzles (Fig. 4,b,d). Further decreas in $Q_{t r}$ leads to transition of the pipeline into collecting mode of operation.

Thus, the angle of $\beta=180^{\circ}$ is more favorable for decreasing the length of water-dispensing segment. Therefore, it is recommended to install nozzles which are situated at the beginning of pipeline at an angle of $\beta=180^{\circ}$.

\section{Conclusion}

The influence of transit water flow rate on water dispensation and inflow into a pressure pipeline with nozzles installed in its wall was investigated. The angle $\beta$ between vectors of velocities of main stream in the pipeline and directions of jets were assigned the values: $180^{\circ}$; 
$225^{\circ} ; 270^{\circ} ; 315^{\circ} ; 360^{\circ}$. Correspondingly, the value of the angle $\beta$ of inflow jet for the inflow nozzle was by $180^{\circ}$ less than that for the outflow nozzles. The increase in the transit flow rate $Q_{t r}$ caused the increase in non-uniformity of the distribution of working heads and of flow rates along the pipeline over the dispensing segment. Over the collecting segment, the inverse tendency was observed.

\section{References}

[1] Yakhno O. M. Napirni potoky zi zminnymy kharakterystykamy: monohrafiia / O. M. Yakhno, V. V. Cherniuk , R. M. Hnativ. - Lviv: NU “Lvivska politekhnika”, 2016. - 408 s.

[2] Cherniuk V. V. Hidravlichnyi rozrakhunok trubchastykh vodozabirnykh oholovkiv z bichnymy vodopryimalnymy viknamy / V. V. Cherniuk, M. P. Bosak, O. H. Hvozdetskyi // Visn. Nats. un-tu "Lvivska politekhnika". Teoriia i praktyka budivnytstva. - Lviv: NU LP. 2012. - № 737. - S. 213-225.

[3] Voloshchuk V. A. Doslidzhennia hidravlichnykh oporiv i hidravlichni rozrakhunky truboprovodiv z dyskretno zminnymy vytratamy uzdovzh potoku: avtoref. dys. na zdobuttia nauk. stupenia kand. tekhn. nauk: spets. 05.23.16 "Hidravlika i inzhenerna hidrolohiia" / V. A. Voloshchuk. - Rivne: Rivnensk. derzh. tekhn. un-t, 2001. - 20 s.

[4] Kravchuk A. M. Hidravlika zminnoi masy napirnykh truboprovodiv tekhnichnykh system: avtoref. dys. na zdobuttia nauk. stupenia dokt. tekhn. nauk: spets. 05.23.16 "Hidravlika i inzhenerna hidrolohiia" / A. M. Kravchuk. - K., 2004. - 35 s.

[5] Chernyshov D. O. Vplyv hidrodynamiky potoku na kharakterystyky roboty rozpodilchykh truboprovodiv: avtoref. dys. na zdobuttia nauk. stupenia kand. tekhn. nauk: spets. 05.23.16 "Hidravlika i inzhenerna hidrolohiia"/ D. O. Chernyshov. -K., 2005. - 20s.

[6] Cherniuk V. V. Stend dlia doslidzhennia prytoku v napirnyi truboprovid-zbyrach, prokladenyi $\mathrm{u}$ pototsi ridyny / V. V. Cherniuk, V. V. Ivaniv // Problemy vodopostachannia, vodovidvedennia ta hidravliky. Nauk.-tekhn. zbirnyk. Vypusk 25. - K.: Kyiv. nats. un-t budivnytstva i arkhitektury, 2015. - S. 286-294.

[7] Vasyl Ivaniv. Influence of Jet-To-Main Stream Turning Angle in Fluid Flow from Cylindrical Nozzle of Collector-Pipeline on Flow Coefficient / Ivaniv Vasyl, Cherniuk Volodymyr // Czasopismo Inżynierii lądowej, środowiska i architektury. Journal of civil engineering, environment and architecture (p-ISSN 2300-5130), (e-ISSN 2300-8903). JCEEA, tom XXXIII, z. 63 (4/2016), październik-grudzień 2016. - S. 229-238.

[8] Smyislov V. V. Gidravlicheskiy raschet perforirovannyih tsilindricheskih truboprovodov s razdachey raskhoda / V. V. Smyislov, N. O. Ezerskiy // Gidravlika i gidrotehnika. - Vyip. 30. - 1980. - S. 52-59.

[9] Cherniuk V. V. Vplyv tranzytnoi vytraty vody na rozdachu ta prytik kriz nasadky v napirnomu truboprovodi / V. V. Cherniuk, V. V. Ivaniv // Visn. Nats. un-tu "Lvivska politekhnika". Teoriia i praktyka budivnytstva. - Lviv: NU "Lvivska politekhnika". - 2016. № 844. - S. 216-227. 